\title{
Influence of Trolox and Alpha-Lipoic Acid on Post-Thawed Prrlak Ram Sperm Parameters, Oxidative Stress and DNA Damage in Non- Breeding Season
}

\author{
Fatih AVDATEK ${ }^{*}$, Deniz YENİ1, Muhammed Kürşad BİRDANE², Mustafa GÜNDOĞAN¹ \\ 1 Afyon Kocatepe University, Faculty of Veterinary Medicine, Reproduction and Artificial Insemination Department, 03200, \\ Afyonkarahisar, Turkey \\ ${ }^{2}$ Afyon Kocatepe University, Faculty of Veterinary Medicine, Obstetrics and Gynecology Department, 03200, Afyonkarahisar, \\ Turkey
}

\begin{abstract}
The present study was conducted to examine the protective roles of trolox and alpha-lipoic on post-thawed Pirlak ram sperm parameters, oxidative stress and DNA damage in non-breeding season. Semen samples from 5 healty Pirlak rams (2-3 years of age) were used in the study. Six ejaculates for each rams were collected and pooled. Ejaculates were split into three aliquots and diluted to a final concentration of $150 \times 10^{6}$ spermatozoa $/ \mathrm{ml}$ with the base extender containing $1 \mathrm{mM}$ alpha lipoic acid, $1 \mathrm{mM}$ trolox and no additive (control) were cooled to $5{ }^{\circ} \mathrm{C}$ and equilibrated for $3 \mathrm{~h}$ then frozen in $0.25 \mathrm{ml}$ French straws. Samples were thawed in $37^{\circ} \mathrm{C}$ and evaluated in terms of spermatological parameters, DNA damage, oxidative stress. Sperm motility was increased, acrosome rate and DNA damage were decreased significantly $(\mathrm{p}<0.05)$ in ALA, head abnormal sperm rate and membrane integrity were increased, acrosome rate and DNA damege were decreased significantly $(\mathrm{P}<0.05)$ in trolox when compared to the control group. Compared with the control group, reductions in spermatozoon MDA and GSH levels were statistically significant $(\mathrm{P}<0.05)$ in lipoic acid and trolox groups. Results of this study suggest that alphalipoic acid and trolox improve sperm parmeters, oxidative stress and DNA damage in non-breeding season.
\end{abstract}

Keywords: Alpha-lipoic acid, Non-breeding season, Ram sperm, Trolox.

Sezon Dışı Pırlak Koç Sperma Sulandırıcısına İlave Edilen Lipoik Asid ve Trolox'un Dondurma ve Çözdürme Sonrası Spermatolojik Parametreler, Oksidatif Stres ve DNA Hasarı Üzerine Etkileri

ÖZ

Bu çalışmanın amacı sezon dışı dönemde Pırlak koç sperma sulandırıcısına ilave edilen trolox ve alfa lipoik asitin (ALA) çözüm sonu spermatolojik parametreler, oksidatif stres ve DNA hasarı üzerine etkileri araştırıldı. Çalışmada sperma örnekleri 5 sağlıklı Pırlak koçtan (2-3 yaş) elde edildi ve her koçtan 6 ejakulat toplanarak karıştırıldı. Ejakulatlar ml'de $150 x 10^{6}$ spermatozoon olacak şekilde antioksidan içermeyen (kontrol) ve antioksidan içeren $1 \mathrm{mM}$ ALA ve $1 \mathrm{mM}$ trolox sulandırıcılar ile sulandırıldı. Sulandırılan örnekler 0,25 ml'lik payetlerde $5{ }^{\circ} \mathrm{C}$ 'de 3 saat ekilibrasyona tabi tutularak sivı azot buharında donduruldu,37 ${ }^{\circ} \mathrm{C}^{\prime}$ de çözdürülerek spermatolojik parametreler, DNA hasarı, oksidatif stres açısından değerlendirildi. ALA grubunda kontrol grubuna göre spermatozoa motilitesi, akrozom ve DNA bütünlüğü istatistiki $(p<0.05)$ olarak daha yüksek bulundu. Trolox grubunda kontrol grubuna göre daha yüksek akrozom ve membran bütünlüğ̈ ile daha az DNA hasar1 tespit edildi. $(\mathrm{p}<0.05)$. Kontrol grubu ile karşılaştırıldığında, ALA ve trolox gruplarındaki oksidatif stres parametrelerindeki azalmalar istatistikî olarak önemli $(\mathrm{P}<0.05)$ bulundu. Bu çalışmanın sonuçlarına göre üreme mevsimi dışında Pırlak koç sperma sulandırıcısına ilave edilen ALA ve troloxun çözüm sonu spermatolojik parametreleri, oksidatif stresi ve DNA hasarına karşı koruyucu bir etki gösterdiği kanaatine varıldı.

Anahtar Kelimeler: Alfa lipoik asit, sezon dişı üreme, koç spermatozoon, trolox.

To cite this article: Avdatek F. Yeni D. Birdane M.K. Gündoğan M. Influence of Trolox and Alpha-Lipoic Acid on Post-Thawed Purlak Ram Sperm Parameters, Oxidative Stress and DNA Damage in Non-Breeding Season. Kocatepe Vet J. (2019) 12(3):363-369

Submission: 17.07.2019 Accepted: 29.08.2019 Published Online: 30.08 .2019

ORCID ID; FA: 0000-0003-2345-8826, DY: 0000-0002-9105-5677, MKB: 0000-0002-9683-4979,

MG: 0000-0002-3292-4625

*Corresponding author e-mail: favdatek@aku.edu.tr 


\section{GİRİŞ}

Günümüzde koç ve teke spermalarının dondurularak suni tohumlama uygulamalarında kullanilması sonucu elde edilen başarı tatmin edici değildir. Bunun da en önemli nedenlerinden bir tanesi dondurulup çözdürülmesi sonucunda elde edilen sperma kalitesinin istenen seviyede olmamasıdır. Gerek küçük ruminantlar da bu problemleri ortadan kaldirmak gerekse büyük ruminantlar da elde edilen başarıy daha da ilerletmek için spermanın dondurulmasında farklı kimyasal maddeler kullanılarak spermanın uzun süre saklanma çalışmaları devam etmektedir. Genetik materyalin önemli bir parçasını oluşturan erkek gamet hücreleri olan spermatozoitlerin dondurulması nesli tükenmekte olan, değerli, eşsiz hayvanların genetik korunması için son derece önemli bir araç haline gelmiştir.

Kriyopreservasyon; hücrelerin dondurularak uzun yillar saklanmasi anlamına gelmektedir. Kriyopreservasyon işleminde amaç çok düşük 1sıda canlı bir hücrenin veya dokunun minumum hasarla fonksiyon kaybı olmaksızın uzun süreli saklanmasıdır. Spermanın sulandırılması, soğutulması, dondurulması ve çözdürülmesi aşamalarını kapsamaktadır (Trounson 1990, Ba1ley ve Bilodeau 2000). Sperma sulandiricisina katilan antioksidanlar ve katk1 maddeleri spermatozoa mitokondrisi ve akrozomunun fonksiyonel bütünlüğü üzerine soğuktan koruyucu etki yapar. Böylece, ATP enerjisinin üretilmesini sağlayarak spermanın çözdürülmesi sonrasi spermatozoa motilitesini artırmaktadır. (Shiva ve ark. 2010) Antioksidan ilavesi spermatozoitlerin saklanması işlemi süresince oksidatif stresi azaltarak etkileyebilmekte ve böylelikle soğutulmuş sperma kalitesini artırmaktadır. (Bilodeau ve ark. 2001) Antioksidanlarin sperma kalitesini artırarak, DNA hasarını önleyerek ve lökositler tarafindan üretilen reaktif oksijen türevlerinin (ROT) süpürücüsü olarak spermotozoonları korumaktadır.

Vitamin E yağda çözünen ve hücre membranındaki en önemli zincir kırıcı antioksidandır. Spermatozoon motilitesini ve sayısını artırır, lipid peroksidasyonu azaltıp spermatozoonun yaşayabilirliğini artırmaktadır. E vitamini; oksidatif strese karşı koruyucu özelliğe sahiptir. (Akiyama 1999) En aktif formu alfatokoferoldür. Çok güçlü bir antioksidan olan alfatokoferolün en önemli görevi serbest oksijen radikallerinin ataklarına karşı membran lipidlerindeki doymamış yağ asitlerini korumaktır (Rice ve Kennedy 1988) Alfa-tokoferolün antioksidan etkisi yüksek oksijen konsantrasyonlarında etkilidir (Deichsel ve ark. 2008). Genel olarak vitamin E alkoksil radikalini ve lipid peroksili nötralize ederek, lipid peroksidasyonu engellemektedir (Agarwal ve ark. 2003). E vitamini en önemli lipofilik antioksidan ve esasen hücre membranında bulunur bu yüzden membran stabilitesinin korunmasinda yardım etmektedir. E vitamini, doymamış yăg asitlerinden ziyade antioksidan moleküllerinden hidrojen atomu ayırarak serbest radikallerin oluşmasını sağlar böylece, serbest radikal reaksiyon zincirinin kirılmalar meydana gelerek unreaktif olarak bilinen antioksidan radikalleri ortaya çıkar (Ozden ve ark. 2009).

Alfa lipoik asit (ALA) açil grup transferinde ve krebs döngüsünde bir koenzim gibi yardımcı molekül olarak 1951 yilinda Reed ve arkadaşları tarafindan keşfedilmiştir. 1980'li yıllarda bilim camiası tarafından güçlü bir antioksidan olduğu ortaya kondu. ALA hayvanlar ve insanlar tarafindan sentezlenebilmektedir (Carreau 1979) ALA'nın okside ve redükte formlarının antioksidan etkinlikleri vardır. (Packer ve ark. 1995). ALA (thioctic asit olarakta bilinen) vitamin benzeri bir antioksidandır, hücre içini ve dışını çeşitli serbest oksijen radikallerine karş1 korumaktadır (Suzukı ve ark. 1991). Alfa lipoik asit disülfid bir bileşiktir ve pyruvate dehydrogenase and $\alpha$ ketoglutarate dehydrogenase için bir koenzim olarak mitokondride bulunmaktadır. Bu maddenin eksojen olarak ilave edilmesi bağlı olmayan alfa lipoik asit seviyesini artırmaktadır ki bu da hem in vivo hem de in vitro oksidatif stresin azaltılmasinı ve kuvvetli bir antoksidan olarak davranması sağlanabilir. Alfa lipoik asit hem suda hem de yağda çözünen, hücre mebranında lipid peroksidasyonlar dahil serbest radikalleri azaltılmasında ve mitokondri kaynaklı serbest radikal süpürücüleri kadar etkinliği yüksektir (Selvakumar ve ark. 2005).

Bu çalışmada, Pırlak koçlarının spermasının uzun süreli saklanmasında sperma sulandırıcılarına katılan trolox ve ALA'nın sezon dişı dönemde çözüm sonu spermatozoa motilitesi, morfolojisi, ölü-canlı oranı, membran bütünlüğü, oksidatif stres parametreleri ve DNA hasarı üzerine etkilerini belirlemek amaciyla yap1ld.

\section{MATERYAL ve METOD}

$\mathrm{Bu}$ çalışmada hayvan materyali olarak Afyon Kocatepe Üniversitesi Hayvancilik Uygulama ve Araştırma Merkezi bünyesinde bulunan 2-3 yaşlı 5 adet Pırlak ırkı koç kullanıldı. Sezon dişı dönemde koçlardan haftada iki kez suni vajen yardımıyla her bir koçtan toplam 6 ejakulat alındı. Sperma örnekleri bir tüpte birleştirilerek (pooling) dondurma öncesi spermatolojik muayeneleri yapıldıktan sonra 3 eşit hacme ayrıldı Çalışmada dondurma sulandırıcı olarak Tris ana stok solüsyonu (\% 5 gliserol, \% 20 yumurta sar1s1) kullanilarak $1 \mathrm{mM}$ trolox, $1 \mathrm{mM}$ ALA ve herhangi bir antioksidan eklenmeyerek (kontrol) 3 farklı grup oluşturuldu,. ml'de $5 \times 10^{8}$ olacak şekilde dozajlanarak sulandirıldi. Sulandirılan spermalar $5^{\circ} \mathrm{C}$ 'de $2-3$ saat ekilibrasyondan sonra azot buharında dondurularak sıvı azot içinde saklandı. 


\section{Spermatolojik Muayene}

Sperma motilitesi $37^{\circ} \mathrm{C}^{\prime}$ ta 1 sitma tablalı faz kontrast mikroskopta (Olympus CX31, Olympus Optical Co., Ltd., Japan) ve en az 5 alan olacak şekilde 200x lük büyütmede değerlendirilerek \% olarak kaydedildi (Demirci 2002). Anormal spermatozoa oran1 siv1 fikzasyon yöntemi ile belirlendi. Fikzasyon amaçlı 1 ml Hancock sıvısı içine 1-2 damla sperma numunesi damlatılıp iyice karışımları sağlandıktan sonra karışımdan bir damla sperma lam üzerine alınarak üzerine lamel kapatılarak immersiyon objektifinde 1000x faz-kontrast mikroskopta 400 spermatozoon sayılarak anormal spermatozoa oran1 \% ( olarak kaydedildi (Schafer ve Holzmann 2000). Spermatozoon membran bütünlüğü ve canlillğının belirlenmesi amaciyla Hipo Ozmotik Swelling TestEozin (HOST-E) testi uygulandi. Sperma örneklerinin $100 \mathrm{mOsm} / \mathrm{lt}$ 'ye ayarlanmış fruktoz solüsyonu içerisine \% 1'lik eozin-Y ilave edilerek HOST-E solüsyonu hazırlandı. ve $35^{\circ} \mathrm{C}$ de 30 dakika inkübe edilip inkübasyon sonrası froti çekilen lamlar hızlıca kurutularak hazırlandi. Hazırlanan preparatlardan toplam 200 hücre sayıldı ve dört tipe (Tip I: kuyruk şişmiş ve baş boya almamış, HOST + /E- ;Tip II: kuyruk şişmemiş ve baş boya almamış, HOST- / E-; Tip III: kuyruk şişmiş ve baş boya almış, HOST + / $\mathrm{E}+$; Tip IV: kuyruk şişmemiş ve baş boya almış, HOST - / E +) göre spermatozoon başının boya alma ve spermatozoon kuyruğunun kivrilma durumuna göre değerlendirildi (Gündoğan ve ark. 2011). Spermatozoa GSH içeriği Sedlak ve Lindsay (1968) metodu kullanılarak ölçüldü. MDA konsantrasyonu Draper ve Hadley (1990) bildirdiği çift kaynatma metodu ile belirlendi. Spermatozoon DNA hasarının belirlenmesinde Single Cell Gel Electrophoresis (SCGE) yöntemi kullanıldı. Comet assay olarak da adlandirilan bu yöntemde İnanç ve ark. (2019) metodu kullanılarak alkali $\mathrm{pH}$ da farklı molekül ağırlıklarına ve elektrik yüküne sahip DNA moleküllerinin elektriksel alanda göçleri incelendi. Değerlendirme ise elde edilen DNA migrasyon görüntülerine göre yapıldı (Singh ve ark. 2003).
Elde edilen verilerin istatistiksel değerlendirilmesinde tek yönlü varyans analizi (ANOVA) uygulandı. Gruplar arası farkın önemini belirlemek için Post-hoc Duncan testi kullanıldı. Analizler bilgisayar ortamında SPSS (16.0) paket programında gerçekleştirildi.

\section{BULGULAR}

\section{Dondurma-Çözdürme Sonrası Spermatolojik Parametreler}

Dondurma-çözdürme sonrası elde edilen motilite,anormal spermatozoon ve akrozomla ilgili elde edilen bulgular Tablo 1'de sunulmuştur. En yüksek motilite ALA grubunda (\% 58.3 \pm 1.66$)$ tespit edildi $(\mathrm{P}<0.05)$. Akrozom bütünlüğü antioksidan içeren gruplarda $(\% 17,66 \pm 2,21 ; \quad \% 17,91 \pm 2,74)$ kontrol grubuna göre $(28,83 \pm 3,17)$ tüm daha yüksek bulundu $(\mathrm{P}<0.05)$.

\section{Dondurma-Çözdürme Sonrası HOST-ETest Parametreleri}

Dondurma-çözdürme sonrası HOST-E sonucunda elde edilen bulgular Tablo 2'de verildi. Tip I (HOST+/E-) oranı açısından kontrol grubuna göre ALA grubundaki artış, Tip II (HOST-/E-) oranı yönünden kontrol grubuna göre trolox grubundaki azalış ve Tip III (HOST+/E+) oranı bakımından kontrol grubuna göre trolox grubundaki artısin önemli $(\mathrm{P}<0.05)$ olduğu belirlendi.

\section{Dondurma-Çözdürme Sonrası DNA Hasarları}

Dondurma-çözdürme sonrası DNA hasarı yönünden elde edilen bulgular Tablo 3'de sunuldu. Buna göre kontrol grubuna göre trolox ve ALA içeren gruplarında daha yüksek DNA bütünlüğü tespit edildi $(\mathrm{P}<0.05)$.

\section{Dondurma-Çözdürme Sonrası Oksidatif Stres Parametreleri}

Dondurma-çözdürme sonrası oksidatif stres parametrelerine ait bulgular Tablo 4'de verildi. Kontrol grubu ile karşılaşturıldığında, lipoik asit ve trolox gruplarinda spermatozoon MDA ve GSH düzeylerinde, azalmalar istatistikî olarak önemli $(\mathrm{P}<0.05)$ bulundu.

\section{İstatistiksel Analiz}

Tablo 1. Dondurma-çözdürme sonrası spermatolojik parametreler $(\bar{X} \pm \operatorname{SEM}, n: 6)$

Table 1. Spermatological parameters after freezing-thawing ( $\bar{X} \pm$ SEM, n:6)

\begin{tabular}{ccccccc}
\hline Gruplar & $\begin{array}{c}\text { Motilite } \\
\mathbf{( \% )}\end{array}$ & $\begin{array}{c}\text { Bas } \\
\mathbf{( \% )}\end{array}$ & $\begin{array}{c}\text { Orta Kisım } \\
\mathbf{( \% )}\end{array}$ & $\begin{array}{c}\text { Kuyruk } \\
\mathbf{( \% )}\end{array}$ & $\begin{array}{c}\text { Toplam } \\
\mathbf{( \% )}\end{array}$ & $\begin{array}{c}\text { Akrozom } \\
\mathbf{( \% )}\end{array}$ \\
\hline Kontrol & $50.0 \pm 2.58^{\mathrm{b}}$ & $1.08 \pm 0.30^{\mathrm{b}}$ & $0.33 \pm 0.10$ & $7.58 \pm 0.59$ & $9.0 \pm 0.71$ & $28.83 \pm 3.17^{\mathrm{a}}$ \\
Trolox $(\mathbf{1} \mathbf{m M})$ & $45.0 \pm 2.23^{\mathrm{b}}$ & $3.41 \pm 0.62^{\mathrm{a}}$ & $0.25 \pm 0.11$ & $6.66 \pm 1.06$ & $10.33 \pm 1.31$ & $17.66 \pm 2.21^{\mathrm{b}}$ \\
& & & & & & \\
ALA(1mM) & $58.3 \pm 1.66^{\mathrm{a}}$ & $1.66 \pm 0.44^{\mathrm{b}}$ & $0.08 \pm 0.08$ & $8.41 \pm 0.98$ & $10.16 \pm 0.66$ & $17.91 \pm 2.74^{\mathrm{b}}$ \\
\hline
\end{tabular}

a-b: Herbir sütun içerisinde farklı harf taşıyan değerler arasındaki farklar istatistiki açıdan önemlidir $(\mathrm{P}<0.05)$.

ALA: alfa lipoik asit. 
Tablo 2. Dondurma-çözdürme sonrası HOST-Eparametreleri ( $\overline{\mathrm{X}} \pm$ SEM, n:6)

Table 2. HOST-E parameters after freezing-thawing ( $\bar{X} \pm$ SEM, n:6)

\begin{tabular}{ccccc}
\hline Gruplar & $\begin{array}{c}\text { HOST+/E- } \\
\mathbf{( \% )}\end{array}$ & $\begin{array}{c}\text { HOST-/E- } \\
\mathbf{( \% )}\end{array}$ & $\begin{array}{c}\text { HOST+/E+ } \\
\mathbf{( \% )}\end{array}$ & $\begin{array}{c}\text { HOST-/E+ } \\
\mathbf{( \% )}\end{array}$ \\
\hline Kontrol & $42.33 \pm 4.58^{\mathrm{b}}$ & $22.50 \pm 1.31^{\mathrm{a}}$ & $17.00 \pm 4.01^{\mathrm{b}}$ & $18.16 \pm 2.76^{\mathrm{b}}$ \\
Trolox $(\mathbf{1} \mathbf{m M})$ & $34.66 \pm 1.66^{\mathrm{b}}$ & $13.33 \pm 1.60^{\mathrm{b}}$ & $28.33 \pm 1.87$ & $23.66 \pm 2.23^{\mathrm{a}}$ \\
& & & & \\
ALA $(\mathbf{1 m M})$ & $55.83 \pm 2.03^{\mathrm{a}}$ & $23.16 \pm 2.37^{\mathrm{a}}$ & $a 9.50 \pm 1.50^{\mathrm{b}}$ & $11.50 \pm 1.31^{\mathrm{ab}}$
\end{tabular}

a-b: Aynı sütun içerisindeki farklı harf taşıyan değerler arasındaki farklar istatistiki olarak önemlidir $(\mathrm{P}<0.05)$.

ALA: alfa lipoik asit.

HOST + /E- : kuyruk şişmiş ve baş boya almamış

HOST- / E-: kuyruk şişmemiş ve baş boya almamış

HOST + / E +: kuyruk şişmiş ve baş boya almış,

HOST - / E +: kuyruk şişmemiş ve baş boya almış.

Tablo 3. Dondurma-çözdürme sonrası DNA Hasarları ( $\bar{X} \pm$ SEM, n:6)

Table 3. DNA damages after freezing-thawing ( $\bar{X} \pm$ SEM, n:6)

\begin{tabular}{cc}
\hline Gruplar & DNA (AU) \\
\hline Kontrol & $49.00 \pm 7.09^{\mathrm{a}}$ \\
Trolox (1 $\mathbf{m M})$ & $30.50 \pm 3.55^{\mathrm{b}}$ \\
ALA (1mM) & $25.33 \pm 3.44^{\mathrm{b}}$ \\
\hline
\end{tabular}

a-b: Sütun içerisindeki farklı harfler taşıyan değerler arasındaki farklar istatistiki açıdan önemlidir $(\mathrm{P}<0.05)$. ALA: alfa lipoik asit.

Tablo 4. Dondurma-çözdürme sonrası oksidatif stres parametreleri ( $\bar{X} \pm$ SEM, n:6)

Table 4. Oxidative stress parameters after freezing-thawing ( $\bar{X} \pm$ SEM, n:6)

\begin{tabular}{ccc}
\hline Gruplar & $\begin{array}{c}\text { MDA } \\
(\mathbf{n m o l} / \mathbf{m l})\end{array}$ & $\begin{array}{c}\text { GSH } \\
(\mathbf{m g} / \mathbf{d l})\end{array}$ \\
\hline Kontrol & $6.3 \pm 0.61^{\mathrm{a}}$ & $7.2 \pm 0.64^{\mathrm{a}}$ \\
Trolox $(\mathbf{1} \mathbf{~ m M})$ & $4.2 \pm 0.47^{\mathrm{b}}$ & $3.1 \pm 0.45^{\mathrm{b}}$ \\
Lipoik $(\mathbf{1 m M})$ & $3.2 \pm 0.24^{\mathrm{b}}$ & $3.7 \pm 0.43^{\mathrm{b}}$ \\
\hline
\end{tabular}

a-b: Herbir sütundaki farklı harf taşıyan değerler arasındaki farklar istatistiki açıdan önemlidir $(\mathrm{P}<0.05)$.

ALA: alfa lipoik asit.

\section{TARTIŞMA}

Koç spermasının uygun bir şekilde dondurularak sun'i tohunlamada kullanılması koyun yetiştiriciliğini ve ıslahını doğrudan olumlu yönde etkilmektedir. Spermanin dondurulması ve bu esnada gelişen olaylar spermatozoonların fonksiyonlarının hasar görmesine yol açmaktadır. Sperma sulandırıcılarına ilave edilen kryoprotektif maddeler ile antioksidanlar dondurma işleminin ve beraberinde gelişen olumsuz etkilerin en aza indirmesini sağlamaktadır. Dondurulmuşçözdürülmüş spermada azalan antioksidan kapasite ve artan ROT oluşumu, spermatolojik özellikleri ve fertiliteyi olumsuz olarak etkiler. Bu nedenle koç spermasinın dondurulmasında antioksidan maddeler, çözdürme sonrası spermatolojik parametreler üzerine olumlu etkileri olabileceği düşünüldüğünden sperma sulandirıcilarına katılmaktadır (Chen ve ark. 1993, Sinha ve ark. 1996).

Subjektif motilite açısından ALA grubu kontrol grubuna göre belirgin bir üstünlük sağladı $(\mathrm{P}<0.05)$. Akrozom bütünlüğü açısından antioksidan içeren gruplar kontrol grubuna göre olumlu etkisi gözlemlendi $(\mathrm{P}<0.05)$. Başpinar ve ark. (2011) tris bazlı Merinos koç sperması sulandırıcısına farklı 
konsantrasyonlarda (1, 2, $4 \mathrm{mM})$ ALA ilavesi ile dondurma-çözdürme sonucunda kontrole göre $1 \mathrm{mM}$ ilave edilen grupta artışın önemli olduğu bildirdiler. Andreea ve Stela (2010) tris bazlı sperma sulandiricisina vitamin $E$ ve sistein ilave ederek dondurdukları koç spermasında çözüm sonrası vitamin E ilave edilen grupta motilite \% 59,16olarak bildirmektedirler. Anghel ve ark. (2010) tris bazlı koç sperma sulandiricisina faklı konsantrasyonlarda bovine serum albumin (BSA), sistein ve Vitamin E ilave ederek dondurdukları spermalarda çözüm sonrası $1 \mathrm{mM}$ vitamin $\mathrm{E}$ grubunda motilite \% 62,61 olarak bildirmektedirr. O’Flahtery ve ark. (1997) tris sulandiricisi (kontrol) ve tris sulandiricisina vitamin $\mathrm{E}$ ilave ederek iki grup halinde dondurdukları boğa spermalarında çözüm sonrası anormal akrozom oranı sirasiyla $\% 7$ ve $\% 9$ olarak bildirmektedir. Anghel ve ark. (2010) tris bazlı koç sperma sulandirıcisina faklı konsantrasyonlarda bovine serum albumin (BSA), sistein ve vitamin $E$ ilave ederek dondurdukları spermalarda çözüm sonrası $1 \mathrm{mM}$ vitamin $\mathrm{E}$ ilave edilerek dondurulan grupta anormal spermatozoon oranlarını düşürmesi istatistiki olarak anlamlı olduğu bildirmektedirr. Elde edilen sonuçlar bazı araştırmacılar ile uyum gösterirken bazı çalışmalardan yüksek ya da düşük sonuçlar ortaya çıkmasının nedenleri arasında 1rk, mevsim, koçlardaki genotipik değişiklikler, sperma sulandırıcısının içeriği, sulandirıcıda kullanılan yumurta sarısının oranı, sulandırıcıların içerdiği komponentlerin miktar ve oranlarının, farklılığından kaynaklanmış olabileceği düşünülmektedir. Ayrıca bu farklılıklar spermanın sulandirılmasinda ve dondurulmasinda kullanılan tekniklerden çözüm süresi ve sıcaklığındaki değişimlerden ve analizi yapan kişi gibi faktörlerden kaynaklanabilir.

Membran bütünlüğü ve ölü-canlı spermatozoon oranının belirlendiği modifiye HOST-Ebulguları Tablo 2'de sunuldu. Buna göre, HOST+/E- oran1 açısından kontrol grubuna göre ALA grubundaki artış, HOST-/E- oran1 yönünden kontrol grubuna göre trolox grubundaki azalış ve HOST+/E+ oranı bakımından kontrol grubuna göre trolox grubundaki artışın önemli $(\mathrm{P}<0.05)$ olduğu belirlendi. Gündoğan ve ark. (2011) Pırlak koçlarda farklı sulandırıcılar ile kısa süreli saklama çalışmalarında tris bazlı sulandırıcı grubunda sulandirma sonrasi 0 . saatteki ortalama HOST+/E- , HOST-/E- , HOST+/E+ ve HOST/E+ oranlarinı sirasiyla $\% \quad 62, \% \quad 26, \% \quad 3$ ve $\% 9$ olarak bulmuşlardır. Gündoğan ve ark. (2010)'nın Pırlak koçlarda spermanın tris ile sulandırılması sonras1 0. saatteki 25 ve 100 milyon yoğunluklu gruplarda HOST + $/ E$ - oranlarını sirasiyla ortalama \% 58 ve \% 49 olarak bildirmektedirler. Akman (2007) Swiss Albino 1rk1 fare spermatozoonlarındaki optimal hipo-ozmotik ozmolariteyi 20-60 mosm olarak belirledikleri çalışmalarında ortalama $\mathrm{HOST}+/ \mathrm{E}-$, HOST-/E-, HOST+/E+ ve HOST-/E+ oranlarını sirasiyla $\% 29.6 \pm 3.2, \% 23.8 \pm 5.0, \% 18.1 \pm 2.7$ ve
\% $28.6 \pm 1.0$ olarak bulmuştur. Gözlenen farklılıkların temelini 1rk, mevsim ve sperma alma metodu gibi faktörlerin yanı sira sperma sulandırıcılarına katılan antioksidanların farklılı̆̆1 ve spermanın sulandirılmasinda, saklanmasinda ve değerlendirilmesinde kullanılan teknik, çözüm süresi ve sıcaklığındaki değişim ve analizi yapan kişi gibi faktörlerinde oluşturabileceğini düşündürmektedir.

DNA hasar1 yönünden kontrol grubuna göre trolox ve ALA içeren gruplardaki azalmalar istatistikî olarak önemli (P<0.05) bulundu. Ibrahim ve ark. (2008) kız1l geyiklerde yaptıkları bir çalışmada ALA spermanın dondurma-çözdürme sonrası motilite ve yaşama gücünü artırdı̆̆1 bununla beraber DNA hasarını ise azalttığını bildirmektedirler. Hughes ve ark. (1999) farklı yoğunluklarda X ışınlarına maruz kalmış insan spermasında meydana gelen DNA hasarı ve askorbik asit ile vitamin $\mathrm{E}$ ( $\alpha$-tekoferol)'in bu DNA bütünlüğünü ne derece koruduğunu comet analiz yöntemiyle araştırdıkları çalışmalarında $300 \mu \mathrm{M}$ askorbik asitin ve $30 \mu \mathrm{M} \quad \alpha$-tekoferol'ün DNA bütünlüğünün korunmasinda etkili olduğunu bildirmektedirler. DNA hasarında gözlenen farklılıklar arasinda 1rk, mevsim ve sperma alma metodu gibi faktörlerin yanı sıra dondurma işleminde kullanılan sulandırıcılar ile sulandırıcıların içerdiği komponentlerin miktar ve oranları ile sperma sulandırıcılarına katılan antioksidanların farklı olması, spermanin sulandirilmasinda ve dondurulmasinda kullanılan tekniklerin farklılığ1 çözüm süresi ve sıcaklığındaki değissimler gibi etkenlerin de rolü olabilir.

Oksidatif stres parametreleri (MDA ve GSH) açısından ALA ve trolox içeren gruplarda kontrol grubuna göre olumlu etkiler gözlemlendi $(\mathrm{P}<0.05)$. Silva ve ark. (2010) Santa Inês koç sperma sulandircilarina ilave ettikleri $50 \mu \mathrm{M}$ Trolox $/ 10^{8}$ dondurma çözdürme sonrası lipid peroksidasyon düzeyleri üzerine kontrol ve diğer gruplara göre olumlu etki yaptığını ve oksidatif stresin kontrolü amaciyla sperma sulandiricisina ilave edilmesi gerektiğini bildirmiştir. O’Flahtery ve ark. (1997) tris sulandiricisina vitamin $\mathrm{E}$ ilavesi ile dondurdukları boğa spermalarında çözüm sonrası MDA seviyesinin azaldığ1 bildirilmiştir. Sicherle ve ark. (2011) süt bazlı sperma sulandirıcisina $100 \mu \mathrm{g} / \mathrm{ml}$ katalaz ve $100 \mu \mathrm{M}$ trolox ilave ederek dondurdukları koç spermasında çözüm sonrası trolox grubunda MDA seviyesinde kontrole göre düşüş görülmüştür. Andreea ve Stela (2010) tris bazlı sperma sulandırıcısına vitamin E ve sistein ilave ederek dondurdukları koç spermasında çözüm sonrası vitamin $\mathrm{E}$ ilave edilen grupta MDA seviyesindeki azalmanın kontrol gurubuna göre önemli olduğunu bildirmektedirler. Başpınar ve ark. (2011) tris bazlı Merinos koç sperması sulandırıcısına farklı konsantrasyonlarda (1, 2, $4 \mathrm{mM})$ ALA ilavesi ile dondurma-çözdürme sonucunda $1 \mathrm{mM}$ ilave ALA grubunda MDA seviyesi kontrole göre yüksek 
olduğunu bildirmektedirler. Oksidatif stres parametrelerinde literatür bilgileri ile aralarında gözlenen farklılıklar dondurma işleminde kullanılan sulandırıcılar ile sulandırıcıların içerdiği komponentlerin miktar ve oranlarının ve sulandırıcinın antioksidan ilave edilmeden önce santrifüj yapılıp yapılmadığından kaynaklanmış olabileceği gibi spermanın sulandırılmasında ve dondurulmasında kullanılan tekniklerdeki farklilıklara, çözüm süresi ve sicaklı̆̆ındaki değişimlere, analizin yapıldığ1 yöntem ve analizi yapan kişi gibi faktörlere bağlı olarak da meydana gelmiş olabilir.

Sonuç olarak Pırlak 1rkı koçların spermalarının sezon dışı dönemde uzun süreli saklanması sırasında kullanilan ALA ve trolox'un çözüm sonu spermatolojik patametreleri, oksidatif stres parametreleri ve DNA hasarını koruyucu etki sağladığı tespit edilmiştir. Trolox ve ALA ilavesinin koç spermasının uzun süreli saklanmasındaki yararlı sonuçlarının ileriki araştırmalarda suni tohumlama sonrasında fertilite sonuçlarıyla desteklenebileceği kanaatine varıld1.

\section{TEŞEKKÜR}

Bu çalışma Afyon Kocatepe Üniversitesi Bilimsel Araștırma Projeleri Koordinasyon Birimi tarafindan 17.KARIYER. 78 nolu proje ile desteklenmiștir.

Bu çalısma International Congress on Advances in Bioscience and Biotechnology (ICABB 2017) kongresinde sözlü olarak sunulmuştur.

\section{KAYNAKLAR}

Agarwal A, Saleh RA, Bedaiwy MA. Role of reactive oxygen species in the pathophysiology of human reproduction. Fertil Steril. 2003; 79: 829-843.

Akiyama M. In vivo scavenging effects of ethylcysteine on reactive oxygen species in human semen. Nippon Hinyokika Gakkai Zasshi. 1999; 90: 421-428.

Akman O. Swiss Albino Irk1 Farelerde Sperma Kalitesinin Belirlenmesi Amacıyla Hos Testi Sonuçları ve Diğer Spermatolojik Parametreler Arasındaki İlişkinin Araştırılması. Doktora Tezi Selçuk Ü. Sağ. Bil. Enst. 2007.

Andreea A, Stela, Z. Role of antioxidant additives in the protection of the cryopreserved semen against free radicals. Romanian Biotechnological Letters. 2010; 15 (3): 33-41.

Anghel A, Zamfirescu S, Coprean D, Sogorescu E. The effects of cystein, bovine serum albumin and vitamin e on the calitative parameters of frozen-thawed ram semen. Annals of RSCB. 2010; 16 (2): 26-32.

Bailey JL, B1lodeau JF. Cormeir Semen Cryopereservation in domestic animals: A Damaging and Capacitating Phenomenon J. of And. 2000; 21 (1): 1-7.

Başpınar N, Çoyan K, Bucak MN, Ömür AD, Ataman MB, Akalın PP, Güngör Ş, Öztürk C. Koç spermasının ekilibrasyon ve dondurma-çözdürme sonrası spermatolojik ve biyokimyasal parametreleri üzerine lipoik asitin etkisi. Eurasian J. Vet. Sci. 2011; 27 (2): 87-92.

Bilodeau JF, Blanchette S, Gagnon C, S1rard MA. Thiols prevent H2O2-mediated loss of sperm motility in cryopreserved bull semen. Theriogenology. 2001; 56 (2): 275-286.

Carreau JP. Biosynthesis of lipoic acid via unsaturated fatty acids. Methods Enzymol. 1979; 62: 152-158.

Chen Y, Foote RH, Brockett CC. Effect of Sucrose, Trehalose, Hypotaurine, Taurine and Blood Serum on Survival of Frozen Bull Sperm. Crybiology. 1993; 30: 423-431.

Deıchsel K, Palm F, Koblischke P, Budık S, Aurıch C. Effect of a dietary antioxidant supplementation on semen quality in pony stallions. Theriogenology. 2008; 69: 940-945.

Demirci E. Evcil hayvanlarda reprodüksiyon, sun'i tohumlama ve androloji ders notlar1 (1nd ed). F.Ü.Vet.Fak., Ders Teksiri No:53 Elazığ. 2002.

Draper HH, Hadley M. Malondialdehyde determination as index of lipid peroxidation. Methods Enzymol. 1990; 186: $421-430$.

Gündoğan M, Avdatek F, Yeni D. Effect of extenders on motility, morphology and osmotic resistance parameters of ram sperm during liquid storage. Revue Méd. Vét. 2011; 162 (11): 546-551.

Gündoğan M, Yeni D, Avdatek F, Fidan AF. Influence of sperm concentration on the motility, morphology, membrane and DNA integrity along with oxidative stress parameters of ram sperm during liquid storage. Anim. Reprod. Sci. 2010; 122: 200-207.

Hughes CM, Mckelvey-Martin VJ, Lewis SEM. Human sperm DNA integrity assessed by the Comet and ELISA assays. Mutagenesis 1999; 14 (1): 71-75.

Ibrahım SF, Osman K, Das S, Othman AM, Majıd NA, Rahman MPA. A study of the antioxidant effect of alpha lipoic acids on sperm quality. Clinics. 2008; 63: 54550 .

İnanç ME, Çil B, Yeni D, Avdatek F, Orakçı D, Tuncer PB, Türkmen R, Taşdemir U. The effect green tea extract supplementation in bull semen cryopreservation. Kafkas Univ. Vet. Fak. Derg. 2019; 25:703-708.

O'Flaherty CM., Beconi MT., Beorlegui NB. Effect of natural antioxidants, superoxide dismutase and hydrogen peroxide on capacitation of frozen-thawed bull spermatozoa. Andrologia. 1997; 29: 269-275.

Özden S, Catalgol B, Gezcinci S, Arda P, Bolkent S, Alpertunga B. Methiocarb-induced oxidative damage following subacute exposure and the protective effects of vitamin $\mathrm{E}$ and taurine in rats. Food and Chemical Toxicology. 2009; 47: 1676-1684.

Packer L, Witt EH, Tritschler HJ. Alpha-lipoic acid as a biological antioxidant. Free Radic. Biol. Med.1995; 19: 227-250.

Rıce D, Kennedy S. Vitamin E: function and effects of deficiency. Br. Vet. J. (1988; 144: 482-492.

Schafer S, Holzmann A. The use of transmigration and Spermac TM stain to evaluate epididymal cat spermatozoa. Anim. Reprod. Sci. 2000; 59: 201-211.

Sedlak J, Lindsay RHC. Estimation of total, protein bound and nonprotein sulfhydryl groups in tissue with Ellmann's reagent. Anal. Biochem. 1968; 25: 192-205.

Selvakumar E, Prahalathan C, Mythili Y, Varalakshmı P. Beneficial effects of Dl- $\alpha$-lipoic acid on 
cyclophosphamide-induced oxidative stress in mitochondrial fractions of rat testis. Chemico-Biological Interactions. 2005; 152: 59-66.

Shiva SRN, Jagan M, Atreja SK. Effect of adding taurine and trehalose to a tris-based egg yolk extender on buffalo (Bubalus bubalis) sperm following cryopreservation. Anim. Reprod. Sci. 2010; 119: 183-190.

Sicherle CC, Ma1a MS, Bicudo SD, Rodello L, Azevedo HC. Lipit peroxidation and generation of hydrogen peroxide in frozen-thawed ram semen supplemented with catalase or Trolox. Small Rum. Res. 2011; 95: 144-149.

Silva MS, Bicudo SD, Sicherle CC, Rodello L, Gallego IC. Lipit peroxidation and generation of hydrogen peroxidein frozen-thawed ram semen cryopreserved in extenders with antioxidants. Anim. Reprod. Sci. 2010; 122: 118-123.

Singh NP, Muller CH, Berger RE. Effects of age on DNA double-strand breaks and apoptosis in human sperm. Fertil. Steril. 2003; 80 (6): 1420-1430.

Sinha MP, Sinha AK, Prasad RL. The effect of glutathione on motility, enzyme leakage and fertilility of frozen goat semen. Anim. Reprod. Sci. 1996; 41: 237-243.

Suzukı YJ, Tsuchiya M, Packer L. Thioctic acid and dihydrolipoic acid are novel antioxidants which interact with reactive oxygen species. Free. Rad. Res. Commun. 1991; 15: 255-263.

Trounson AO. Cryopresrevation. Brit. Med. Bull. 1990; 147: 427-433. 